\title{
Table of cases
}

\section{United Kingdom}

Foss v Harbottle (1843) 67, ER 189; (1843) 2 Hare 461 53

\section{United States}

Dileo v Ernst \& Young, 901 F2d, 624 (7th Cir, 1990). . .40 
Ding Chen - 9781781004814 Downloaded from PubFactory at 04/26/2023 02:54: via free access 